\title{
Impact of Economic Freedom Index and Corruption Perceptions Index on Corporate Income Tax Revenue in Vietnam
}

\author{
Nguyen Huu Cung, \\ Hanoi University of Industry, Vietnam
}

Doi:10.19044/esj.2019.v15n28p185 URL:http://dx.doi.org/10.19044/esj.2019.v15n28p185

\begin{abstract}
Economic freedom and Corruption are always important issues that governments need to control, due to their impact on the development of each country is very large, especially in developing countries. The purpose in this article is to determine the impact of economic freedom index and corruption perceptions index on corporate income tax revenue. Empirical method was employed on secondary time series data set during the period 1999-2018. Econometric tools were employed to present and analyze the collected data from concerned bodies. The results show that economic freedom index and corruption perceptions index is significantly and positively correlated with corporate income tax revenue at $1 \%$ significance level. Besides, annual rate of inflation has a negative and significant impact on corporate income tax revenue at $10 \%$ significance level.
\end{abstract}

Keyword: Corporate income tax, Income tax, Tax revenue, Vietnam

\section{Introduction}

Fiscal deficit is an important issue and a challenge over the past several decades that developing countries have to find solutions to overcome through stimulating economic growth, higher sales and profits, higher per capita income, thereby increasing revenue from taxes and other sources, including corporate income tax. The rapid expansion in expenditure and low budget revenue are the behind reasons of the long-term increase in fiscal imbalance (Gobachew et al., 2018). However, the increase in tax revenue to offset the budget deficit is not allowed to exceed the endurance of the economy, just enough to meet the necessary spending needs of the government, otherwise be a negative effect of the tax policies on the macro economy. In fact, the main role of a tax system of any country is to raise enough revenue to finance essential expenditures on the goods and services provided by government (Pius and Raymond, 2014). How to raise tax revenues? There are many factors 
effecting tax revenues such as per-capita GDP, per-capita income, industry sector share to GDP, agriculture sector share to GDP, trade openness, share of export and import to GDP, foreign aid, inflation rate, public spending, tax corruption and others. These factors have a positive or negative effect and significant or insignificant on tax revenue. Boukbech et al. (2018) finds that per capita GDP and the value added of agriculture have a positive effect and significant on tax revenues. In another article's results, Abhijit Sen Gupta (2007) confirm that structural factors such as per capita GDP, agriculture share in GDP, trade openness and foreign aid have significant impact on revenue performance of an economy. Agbeyegbe et al. (2006) finds that tax revenue and some factors such as exchange rate changes and higher inflation have a negative effect, whereas tax revenues and trade liberalization is unclear.

In the early stages of development, the countries' budget revenue mainly is from the exploitation of natural resources, foreign aid and some taxes (corporate income tax, natural resource tax, land use tax, license tax, etc.), in which, revenue from corporate income tax as a percentage of total tax revenue accounts for the high proportion. Evidence that according to the statistical data, during the period of 2007 - 2011, revenue from corporate income tax, $13,96 \%$ in China (ranked the 2nd after VAT), 30,73\% in Vietnam (ranked the 1st) (Nguyen Huu Cung, 2015). If the socio-economic development of each country reaches a certain threshold, revenue from other taxes as a percentage of total tax revenue gradually increases and higher than the corporate income tax, such as individual income tax, value added tax. Based on The Huffington Post Canada the first time in Canadian history, more than half of the federal government's revenue in 2014 will come from individual income tax. In fact, corporate income tax has been commonly applied in most countries with different names, such as company income tax, corporate income tax, corporate tax, profit tax and others (Nguyen Huu Cung, 2015). Due to corporate income tax and individual income tax are levied on income. Therefore, the combination of these two taxes is called income tax and be applied in several countries.

Because Vietnam is a developing country, many fields need to be invested. Many resources are exploited including financial resources. Moreover, in the early stages of development, due to the accumulation of capital in the people is not enough, the government's intervention in many socio-economic fields is indispensable. The government not only exploits domestic resources but also looks for foreign capital by government loans or/and investment attraction. Fact in Vietnam, tax revenues as a percentage of total budget revenues are still the most including corporate income tax revenue. Law on corporate income tax was passed on October 5, 2009 by the National Assembly of Vietnam to replace the Law on profit tax, and be formally applied on January 1, 1999. In 2003, Vietnam's corporate income tax 
law has been amended and officially applied on January 1, 2004. The world economic crisis since 2008 has affected the Vietnamese economy in a negative way, this tax has been really modified several articles and took effect on January 1, 2019. Meanwhile, Law on individual income tax was applied on January 1, 2009 and this tax revenue lower than corporate income tax (Hua Liu et al., 2012; Cung Huu Nguyen and Hua Liu, 2014). Average annual, corporate income tax revenue has been increasing over the years and ranked first in the tax system of Vietnam. In the scope of the authors' research, there are not too many articles studying the relationship between corporate income tax revenue and other economic indicators in Vietnam such as capita-per GDP, capita-per income, inflation rate, corruption, tax rate and others, especially quantitative studies. This is an urgent issue that needs to be studied to increase tax revenue in the context that the state budget continues to be in deficit but does not exceed the tolerance of people and businesses. Within the scope of this article, the author determines the impact of economic freedom index and corruption perceptions index on corporate income tax revenue in Vietnam.

\section{Theoretical Framework}

\section{Basic issues of corporate income tax}

According to the Investopedia's definition: "Taxes are involuntary fees levied on individuals or corporations and enforced by a government entity whether local, regional or national - in order to finance government activities. In economics, taxes fall on whomever pays the burden of the tax, whether this is the entity being taxed, like a business, or the end consumers of the business's goods." According to Liu et al. (2012), the application of tax policies of countries has appeared two quite clear trends: Firstly, the tax burden is excessive, the state budget revenue increases rapidly, but it causes great losses to the economy, exceed the endurance of the economy, and consequently, the production of the whole society falls below its potential. Secondly, reduce the tax burden to increase savings, investment, aggregate demand, accumulate capital to expand production scale, but the first time the state budget will be reduced. Thus, taxation is one of the important regulatory instruments on the social and economic development of each country.

Corporate income tax appeared very early in the developmental history of tax. This tax is one of the direct taxes levied on the profits of businesses. This means that it is levied directly to the taxable income of the businesses of goods and services production after deduction of costs in creating sales and taxable income of these businesses. High or low tax rates depend on the viewpoint of income distribution and goals set in income distribution of each country in certain historical period. Its role is to regulate the macro economy, equitable income distribution and state revenues. As a result of tax policies, revenues from taxes in general and corporate income tax in particular are used 
by the government to carry out its functions on the socio-economic issues arising in the development process in the each year or/and each period. Firstly, the central and local governments' main revenue comes from taxes, aims to provide public goods and services for social and public needs, moreover, government needs tax revenue to establish armed forces and the justice system to ensure national safety and social fairness, other functions (Tony Addison and Jörgen Levin, 2012). Secondly, taxes in general and corporate income tax in particular are important tool to contribute to encourage and promote production and business in the direction of the government's comprehensive planning, strategy and development. In economic development, taxes are often used to encourage investment, production. Reasonable tax rates and tax incentives in investment have a great impact on new investment decisions or size expansion of enterprises. In fact, in developed countries as well as in developing countries, taxes are used at tax rate incentives and time incentives to encourage the development of industries that need to encourage development or attract investment. Specifically with corporate income tax, these incentives are usually applied in the form of exemption or reduction of corporate income tax for a certain period of time after investment, or apply different tax rates depending on the region or industry or enterprise. On the one hand, small and medium-sized enterprises have an important role in both developed and developing countries as it provides employment for a large proportion of the labor force. On the other hand, stemming from the inherent flexibility, small and medium-sized enterprises have the strength of technological innovation fast, creating a stable and steady production network in the economy. Thus, tax policies with reasonable exemption and reduction incentives have a great impact on the encouragement and promotion of production and business of these enterprises. Thirdly, corporate income tax is an important tool for the State to perform the function of income redistribution, social justice. In the context of competitive economy, all enterprises have the right to business freedom and equality. Enterprises with a highly skilled workforce and strong financial capacity will have the advantage and opportunity to receive high income, and vice versa for inefficient enterprises. To mitigate this disadvantage, the State uses corporate income tax as a tool to regulate the income of enterprises with high incomes, ensuring the fair contribution requirement of enterprises to the State budget. This can prove that corporate income tax as well as other taxes has an important role in the state budget revenue as well as the operation of state apparatus.

\section{Determinants}

In economic theory as well as practice in countries, there are many factors affecting tax revenue in general and corporate income tax revenue in particular. Firstly, GDP has a positive impact on corporate income tax 
revenue. This means that in constant condition of other factors, an increase in GDP growth rate is an increase in corporate income tax revenue, and vice versa. As the economic growth rate increases over the years, businesses will have higher profits and greater accumulations, encouraging businesses to invest in breadth and depth. Based on this logic, the tax payable by businesses also increases in all taxes. Secondly, inflation rate has a negative relationship with the corporate income tax revenue. Inflation is an important tool that governments use to stimulate the economic growth, but an increase in inflation rate to a certain threshold has a negative effect on economic growth. Until then, a negative impact of inflation rate on the production of goods and services of enterprises towards reducing sales and profit, and thus, the corporate income tax payable will decrease and can be reduced to zero in conditions of prolonged inflation. Thirdly, economic freedom index has a positive effect on corporate income tax revenue. Before 1986, Vietnam's economy developed under the subsidized centralized plan, economic indicators were low, only the existence of state-owned enterprises, not policy to develop private enterprises, not yet a member of any regional and world economic organization. In 1986, Vietnam has begun to develop a competitive free market economy, a member of international economic organizations, an appearance and development of many private and foreign enterprises, an increase of macroeconomic indicators over the years. Under these development conditions, businesses are more efficient in business and production, an increase in sales and profits, and thus, tax payable to the state budget increases, including revenue from corporate income tax. Fourthly, corruption perceptions index has a positive effect on corporate income tax revenue. This means that in constant condition of other factors, an increase in corruption perceptions index is an increase in corporate income tax revenue, and vice versa. In addition, there are a number of other factors that affect corporate income tax revenue such as tax rates, tax administrative procedures, human resource quality of tax authorities, awareness of businesses on tax liability, globalization, etc.

\section{Empirical Evidence}

Graneshwar Ghura (1998) used data for 39 sub-Saharan African countries during 1985-1996 and the result shows that economic policies and corruption effect on the variations in tax revenue-GDP ratios within this group. These ratios rise with a decrease in inflation and corruption, an increase in human capital. Based on the results of this study prove that in economic theory as well as practice in 39 sub-Saharan African countries, the impact of inflation and corruption on tax revenue-GDP ratios is a negative sign. Mossie (2016) studied on determinants of tax revenue in Ethiopia for the period of 19752013, the results show that the impact of inflation on tax revenue is a negative 
and significant, whereas GDP per capita income, foreign aid and industrial value added share of GDP have a positive effect and significant on tax revenue. This result is similar to Graneshwar Ghura (1998) about the relationship between inflation and tax revenue. Other result finds that the effect of inflation on tax revenue is a negative sign, means that an increase in inflation is a decrease in total tax revenues (Lucotte, 2010). An empirical study used forty two years data to analyze a correlative regression and shows that the level of change in income, inflation rate and exchange rate has an effect on tax revenue in Nigeria (Muibi \& Sinbo, 2013). A similar study of Velaj \& Prendi (2014) finds that inflation, unemployment and GDP effect on tax revenue and significant in Albania. The result of Mahdavi (2008) finds that the effect of inflation on tax revenue is a negative sign. A study with the title is "The effect of corruption and governance on tax revenues" finding the relationship among corruption and tax revenues is an adverse effect (Tahseen Ajaz and Eatzaz Ahmad, 2010)

\section{Data and Model}

As analyzed above, in economic theory as well as empirical evidence in countries show that tax revenues in general and corporate income tax revenue in particular are influenced by several different factors. The impact of each factor on its revenue could be a positive or negative sign. To determine exactly the role of each factor, empirical method was employed to perform a regression analysis on the effect of independent variables on dependent variable. The author has built a linear regression model on the relationship between an independent variable and several dependent variables. Within the scope of this article, the author analyzes the relationship between corporate income tax revenue and economic freedom index, corruption perceptions index, inflation rate. To accomplish the purpose of this study, the article uses secondary data in the period 1999 - 2018 collected from different local and international organizations, such as Vietnam Ministry of Finance, World Bank, Transparency International - The Global Anti-Corruption, The Heritage Foundation. The following model was developed based on previous literature. TAX $=$ F(CORRUP, FREEDOM, INFL)

TAX $=\beta_{0}+\beta_{1}$ CORRUP $+\beta_{2}$ FREEDOM $+\beta_{3}$ INFLN $+\varepsilon_{\mathrm{t}}$

Where, TAX is Corporate Income Tax Revenue (Bill. VND)

Where, $\beta_{0}$ is Intercept Term and $\beta_{1}, \beta_{2}, \beta_{3}$ are Coefficients

CORRUP $=$ Corruption Perceptions Index (score)

FREEDOM = Economic Freedom Index (score)

INFLN = Annual Inflation Rate (annual \%)

$\varepsilon=$ Error Variable 
With the given data this article has run the regression in Vietnam where TAX represents the dependent variable and represents corporate income tax revenue of the country, while others are the independent variables.

\section{Results and Discussion}

\section{Correlation Analysis between TAX and Independent Variables}

In table below, suggest that corruption perceptions index, economic freedom index and inflation have statistically significant effects on corporate income tax revenue. The impact of factors on corporate income tax revenue can be a positive or negative sign.

Table 4.1. Correlation Matrix between TR and Independent Variables.

\begin{tabular}{llcccc}
\hline \hline & & TAX & CORRUP & FREEDOM & INFL \\
\hline \hline \multirow{3}{*}{ Pearson Correlation } & TAX & 1 & & & \\
& CORRUP & 0.960 & 1 & & \\
& FREEDOM & 0.816 & 0.749 & 1 & \\
& INFL & -0.044 & -0.049 & 0.362 & 1 \\
\hline \hline
\end{tabular}

Source: Correlation Output of Data Collected

The correlation results show that there is a positive correlation between corporate income tax revenue and corruption perceptions index, economic freedom index, while there is a negative correlation between corporate income tax revenue and annual inflation rate.

Table 4.2: Regression Results

\begin{tabular}{crrrr} 
Variable & Coefficient & Std. Error & t-Statistic & Prob. \\
\hline \hline C & -1294175. & 126361.4 & -10.24186 & 0.0000 \\
CORRUP & 27814.93 & 3698.489 & 7.520621 & 0.0000 \\
FREEDOM & 14168.51 & 4133.447 & 3.427771 & 0.0035 \\
INFL & -2971.401 & 1472.337 & -2.018153 & 0.0607 \\
\hline \hline R-squared & 0.955794 & F-statistic & & 115.3144 \\
Adjusted R-squared & 0.947506 & Prob(F-statistic) & & 0.000000 \\
Durbin-Watson stat & 1.961141 & & & \\
\hline \hline
\end{tabular}

Source: Correlation Output of Data Collected
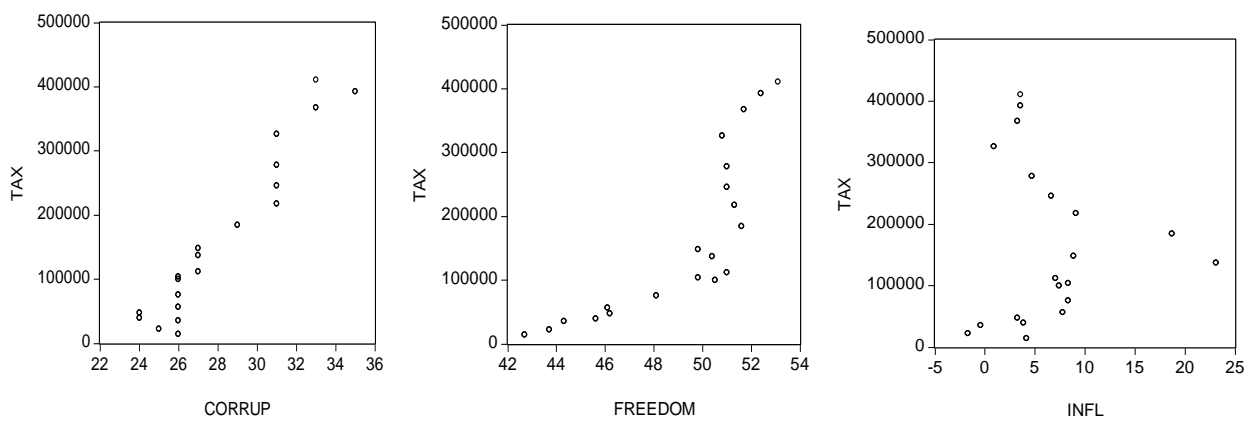


\section{Model Fitness}

Regression results in Table 4.2 show, the explanatory degree of the determinants of corporate income tax revenue in terms of $\mathrm{R}^{2}$ is $95.57 \%$. This means that around 95 percent of variation in corporate income tax revenue is explained by this model through independent variables like corruption perceptions index, economic freedom index, inflation rate. The value $d$ of Durbin-Watson test is $d=1.961141$, meanwhile the significance level $\alpha=5 \%$ $=0.05$, the sample numbers $\mathrm{n}=20$, number of independent variable in the model $\mathrm{k}^{\prime}=3$, inferred $d_{L}=0.998$ and $d_{U}=1.676$. Due to $d>d_{U}$, so the results show that the model is not an autocorrelation phenomena. The regression results in this article also show, $\operatorname{Prob}(\mathrm{F}$-statistic $)=0.000000$ which is less than 0.01 . This could be concluded that the model is suitable at $1 \%$ significance level. The author will continue to analyze the regression results of each factor. Corruption Perceptions Index

In table 4.2, corruption perceptions index as depicted in the above regression equation has a positive and significant effect on corporate income tax revenue at $1 \%$ significance level. This value implies that in constant condition of other factors, a 1.0 score increase in corruption perceptions index results in VND 27814.93 billion increase in corporate income tax revenue. This shows that Vietnam has tried to be overt and transparent in operating macroeconomics. Evidence that Vietnam's corruption perceptions index has increased over the years during the period 1999-2018, for example, 26 score in 1999 was increased to 33 score in 2018. However, Vietnam's corruption perceptions index is still slower and increases slowly compared to other countries in the region (Japan: 60 score in 1999 and 73 score in 2018; Taiwan: 56 score in 1999 and 63 score in 2018; South Korea: 38 score in 1999 and 57 score in 2018; Thailand: 32 score in 1999 and 36 score in 2018). High or low corruption perceptions index also reflects the economic development of each country, for example, GDP at current prices in these countries to be higher than Vietnam (Japan: USD 4,562 billion in 1999 and USD 4,971 billion in 2018; South Korea: USD 485.248 billion in 1999 and USD 1,619 billion in 2018; Thailand: USD 126.669 billion in 1999 and USD 504.993 billion in 2018; Vietnam: USD 28.684 billion in 1999 and USD 244.948 billion in 2018) (World Bank Data).

\section{Economic Freedom Index}

Similarly, economic freedom index has a positive and significant effect on corporate income tax revenue at $1 \%$ significance level. More specifically, in constant condition of other factors, a 1.0 score increase in economic freedom index results in approximately raise VND 14168.51 billion in corporate income tax revenue. This also is a true reflection with expanding Vietnam's international economic relations. Based on the web portal of Vietnam Ministry of Foreign Affairs, Vietnam has established diplomatic 
relations with more than 170 countries around the world, expanding trade relations, exporting goods to more than 230 markets of countries and territories, signing over 90 bilateral trade agreements, nearly 60 investment encouragement and protection agreements. At the same time, Vietnam is actively participating and promoting its membership in international economic organizations, such as WTO, ASEAN, APEC, ASEM, others. This result is a new finding of the author in the case study of Vietnam.

\section{Inflation Rate}

Annual inflation rate is an important economic indicator and is used as a measure of macroeconomic instability, therefore has a significant effect on tax revenue in general and corporate income tax revenue in particular. The regression result shows that inflation rate has a negative effect and significant on corporate income tax revenue at $10 \%$ significance level. This means that in constant condition of other factors, a $1 \%$ increase in inflation results in VND 2971.401 billion decrease in corporate income tax revenue. This result is consistent with the finding of Mahdavi (2008), Mossie (2016), Graneshwar Ghura (1998), (Lucotte, 2010). What are the causes? Firstly, with the average annual inflation rate of $6.5 \%$ during the period 1999-2018 is a relatively high index compared to the power of Vietnam's economy. More specifically, Vietnam has been in an economic crisis since 2008 (23.116\% of inflation rate in 2008) and so far that influence is still a challenge to the Vietnamese economy. Therefore, negatively affecting economic growth (only maintained around $6.5 \%$ in recent years), reducing the production and business efficiency of enterprises, sales and profit, and a decrease in corporate income tax revenue. Secondly, the relatively high inflation rates have created an increase in cost of living related to the loss of purchasing power of money, which ultimately tax evasion was done by taxpayers and reducing the real revenue of corporate income tax. Moreover, in fact, Vietnam's informal economy has always existed and tends to increase by annual inflation rate and cash payments, therefore tax revenue in general and corporate income tax revenue in particular are collected less. This result proves that inflation rate has been a challenge for Vietnam in operating macro economy in many years.

Although the results show that corruption perceptions index, economic freedom index and annual inflation rate effect on corporate income tax revenue, but there are still a number of other factors that could also affect corporate income tax revenue such as GDP growth, organizational structure of tax collection and administration, responsibility of taxpayers, tax burden, others. Therefore, this is the research gap for the next studies of the author.

\section{Conclusion and Policy Implication}

In this article, the author finds three factors effecting corporate income tax revenue, including corruption perceptions index, economic freedom index 
and inflation rate. Firstly, the impact of corruption perceptions index on corporate income tax revenue is a positive sign and significant. The result implies that Vietnam continues to improve its corruption perceptions index by drastically combating corruption in all socio-economic sectors including tax collection management. Secondly, the relationship between economic freedom index and corporate income tax revenue is a positive sign and its effect is significant. The result also implies that Vietnam continues to become an active member of international economic organizations and continue to fully and seriously implement commitments and actively participate in activities within the framework of these organizations. Moreover, Vietnam needs to be more open in tax policies to attract foreign investment and avoid double taxation. Thirdly, annual inflation rate has a negative and negligible effect on corporate income tax revenue. Inflation is an important tool to regulate the economy in the direction of stimulating economic growth. However, Vietnam's annual inflation rate is relatively high, so it has become one of the factors affecting the economic growth rate, many businesses went bankrupt or narrowed production size, business efficiency of enterprises are generally not at a high growth rate. To promote the positivity of inflation, Vietnam continues to control it at an appropriate level with the power of the economy, improving the purchasing power of money.

\section{References:}

1. Tencer (2013). Canada's Tax Burden Shifting Corporations Onto People: Economists. The Huffington Post Canada. https://www.huffingtonpost.ca/2013/11/24/corporate-personal-taxescanada_n_4333694.html

2. Nguyen (2015). Corporate Income Tax Burden and Its Determinants: Evidence from Vietnam. Advances in Management and Applied Economics, Vol. 5, No. 3, pp. 103-120.

3. Gobachew et al. (2018). Determinants of Tax Revenue in Ethiopia. Economics, 6(6): 58-64. DOI: 10.11648/j.eco.20170606.11

4. Pius and Raymond (2014). Factors affecting tax revenue in Pakistan. International Journal of Advanced Research, volume2, issue 2,449458.

5. Boukbech et al. (2018). Determinants of tax revenues: Evidence from a sample of Lower Middle Income countries. Munich Personal RePEc Archive, MPRA Paper No. 90268, posted 1 December 2018 17:45 UTC. https://mpra.ub.uni-muenchen.de/90268/

6. Gupta (2007). Determinants of Tax Revenue Efforts in Developing Countries. IMF Working Paper, WP/07/184. https://www.imf.org/en/Publications/WP/Issues/2016/12/31/Determi nants-of-Tax-Revenue-Efforts-in-Developing-Countries-21040 
7. Agbeyegbe et al. (2006). Trade liberalization, exchange rate changes, and tax revenue in sub-Saharan Africa. Journal of Asian Economics, 17, 261-284.

8. National Assembly of Vietnam. Law on corporate income tax. Issued on 10/5/1997. (Vietnamese Version).

9. Nguyen and Liu (2014). A Comparative Study on Individual Income Tax Burden of Vietnam and China, Business and Management Research, Vol. 3, No. 2, pp. 60-66.

10. Liu et al. (2012). Analysis of Differences of The Personal Income Tax Regime between Vietnam and China. In Proc. of 2nd International Conference on Financial Management and Economics (ICFME), Singapore, 2012, Vol.43, pp. 231-237, ISSN: 2010-4626, ISBN: 978981-07-2856-4. https://www.transparency.org/research/cpi/overview

11. Addison and Levin (2012). The determinants of tax revenue in subSaharan Africa. 2012. https://www.semanticscholar.org/paper/The-determinants-of-taxrevenue-in-sub-Saharan-AddisonLevin/84e0fb345d98749b880a559a39ff8559cab96723 https://www.investopedia.com/terms/t/taxes.asp

12. Liu et al. (2012). Analysis of Differences of The Personal Income Tax Regime between Vietnam and China. In Proc. of 2nd International Conference on Financial Management and Economics (ICFME), Singapore, 2012, Vol.43, pp. 231-237, ISSN: 2010-4626, ISBN: 978981-07-2856-4.

13. Mossie (2016). Determinants of Tax Revenue in Ethiopia (Johansen Co-Integration Approach). International Journal of Business, Economics and Management, 3(6): 69-84. DOI: $10.18488 /$ journal.62/2016.3.6/62.6.69.84

14. Ghura (1998). Tax Revenue in Sub-Saharan Africa: Effects of Economic Policies and Corruption. IMF Working Paper, Washington: International Monetary Fund, pp.1-25.

15. Lucotte (2010). The choice of adopting inflation targeting in emerging economies: Do domestic institutions matter?", MPRA Paper27118, University Library of Munich, Germany.

16. Muibi and Sinbo (2013). Macroeconomic Determinants of Tax Revenue in Nigeria (1970-2011). World Applied Sciences Journal 28 (1): 27-35, 2013 ISSN 1818-4952. IDOSI Publications, 2013 DOI: 10.5829/idosi.wasj.2013.28.01.1189.

17. Mahdavi (2008). The level and composition of tax revenue in developing countries. International review of economic and finance, Volume

17 ,

Issue 4, pp.607-617. 
https://doi.org/10.1016/j.iref.2008.01.001

https://data.worldbank.org/indicator/NY.GDP.MKTP.CD

18. http://www.mofahcm.gov.vn/vi/mofa/nr091019080134/ns120222162 $217 /$

19. Ajaz and Ahmad (2010). The Effect of Corruption and Governance on Tax Revenues. The Pakistan Development Review, Vol. 49, No. 4, pp. 405-417 